\title{
Labor Market Imbalances and Personnel Recruitment
}

\author{
Raimondo Ingrassia \\ Department of Economics, Business and Statistics, University of Palermo, Palermo, Italy \\ Email: raimondo.ingrassia@unipa.it
}

How to cite this paper: Ingrassia, R. (2019) Labor Market Imbalances and Personnel Recruitment. American Journal of Industrial and Business Management, 9, 1376-1394. https://doi.org/10.4236/ajibm.2019.96090

Received: May 29, 2019

Accepted: June 23, 2019

Published: June 26, 2019

Copyright $\odot 2019$ by author(s) and Scientific Research Publishing Inc. This work is licensed under the Creative Commons Attribution International License (CC BY 4.0).

http://creativecommons.org/licenses/by/4.0/

\begin{abstract}
When the economy of a country starts to expand or collapse in wealth, it is reflected in the labor market with an impact on employment and personnel recruitment processes. The aim of this article is to investigate the relationship between personnel recruitment and job market imbalances in the various developmental conditions of the macroeconomic environment. Research findings show that employers tend to adopt more active, formal, competitive, targeted, and selective search behaviors in the positive cycles of the economy and employment. Conversely, in downturns of the economy and employment, employers tend to be more passive and defensive, relying on informal relationships and, in some cases, institutional intermediaries. Research contributions, managerial implications and limits of this study conclude the article.
\end{abstract}

\section{Keywords}

Personnel Recruitment, Staffing, Economic Cycles, Labor Market Imbalances, Local Labor Market, Italian Regions

\section{Introduction}

There are many contributing factors which influence companies in their research strategies for personnel: the size of the company, the characteristics of employment, the social environment, market strategies, labor policies and technologies ${ }^{1}$. One of these factors is the labor market seen from an economic context. When the economy of a country is in a state of expansion or contraction in wealth, it is reflected in the labor market, causing changes in employment. International research has confirmed various aspects of this phenomenon. The Demos survey found that the contingent imbalances in the labor market can unexpectedly alter the balance of power between the demand and supply of la-

${ }^{1}$ Personnel recruitment is the set of decisions and actions taken by the employer to identify, attract and find suitable candidates to fill vacant job positions resulting from the business planning process. 
bor, influencing personnel recruitment strategies [1]. The Kelly Services survey found that personnel recruitment is perceived differently in the world among countries with advanced economies and developing countries [2]. The Recruiter.com report [3] shows how information and communication technologies (ICT) are used today to support searches for more sophisticated staff both in conditions of high demand and high labor supply².

The aim of this article is to investigate the relationship between personnel recruitment and labor market imbalances in the various conditions of development in a macroeconomic context. This article, therefore, addresses the following issues: the relationships between economic cycles and labor market imbalances; personnel recruitment and research behavior in conditions of imbalance in the labor market; a verification of these relationships in the Italian regional labor markets. Summary of results, contributions to research, managerial implications and limitations of the study conclude the article. Empirical research, studies, textbooks, surveys, reports, national and international data and statistics published on the subject were used. All these sources have been taken from the google scholar database by typing the following keywords: personnel recruitment, staffing, economic cycles, labor market imbalances, and selecting the sources that explicitly dealt with the topic of personnel recruitment in conditions of imbalance in the labor market.

\section{Economic Cycles and Labor Market Imbalances}

The labor market is a part of the environment in which a company interacts in order to carry out some of its human resource management strategies. From a business perspective, the labor market stratifies into levels relatively interdependent of each other [4] [5] [6]. A general level, common to all companies, in which the labor market is seen as an aggregate of supply and demand and as a set of institutional rules and actors. In this case, we talk about the general labor market. There is a sectoral level that focuses on the dynamics of labor supply and demand and on the institutions that regulate it in relation to specific production sectors, geographical areas or professional groups. In this case, we talk about the target labor market. Also in a company level, the demand and supply dynamics of labor and regulatory mechanisms are considered within the boundaries of a specific organization. In this case, we talk about internal labor markets [7] [8] [9].

The labor market, like any other market, tends to converge towards positions of equilibrium according to the quantities demanded and offered, but this does not necessarily satisfy all the actors in the system: jobs may remain vacant, un${ }^{2}$ Demos is a British think tank. It has conducted a recruitment study based on over 40 interviews with industry professionals, a workshop and an analysis of the literature on the subject. Kelly Services, a leading global company in the field of human resources services with a turnover of 5.4 billion dollars in 2014, has collected the opinions of more than 2000 selection process managers in 10 countries around the world, including Russia, India, Germany, Switzerland and Singapore. Recruiter.com is an online recruitment platform. It has produced a hypertext report with reflections, testimonies and data on current trends in recruitment technologies. 
employment high, wages on the limits of subsistence [10] [11]. Numerous studies of economic matrices have shown that the general macroeconomic conditions of a country can alter the balance [12] [13] [14] [15]. The studies which have most grasped the relationship between the labor market and general economic conditions can be traced back to The Theories of Economic Cycles [10] [16] [17] [18] [19].

According to the theories of cycles, the temporal dynamics of the economy are characterized by a succession of expansive and recessive periods that influence both the demand for labor, creating or destroying jobs [12], and job offers, encouraging (or not) participation in the market, influencing the resilience of job seekers, and raising or lowering their wage expectations. These cycles may involve the general labor market or individual productive sectors, particular geographical areas or specific professional groups. This is what happens, for example, in mature or innovative sectors, in depressed and developed regional areas, for specific professions, trades or job positions.

In the expansive cycles of the economy, the prospects for growth in market demand multiply production opportunities, leading to an increase in job vacancies and employment ${ }^{3}$. When the demand for labor rises, companies tend to limit turnover, offer higher salaries, compete with other employers to attract a scarce workforce, lower recruitment standards, and use more sophisticated recruitment techniques [10] [20] [21] [22] [23].

However, these phases of expansion are not always characterized by an increase in demand and a reduction in unemployment. This is because the active population can increase participation in the labor market, attracted to a greater probability of employment, or due to the relationship between demand and supply not being realized efficiently [23]. Furthermore, there are reasons as to why there may be a delay or absence of employment growth. It is attributable to specific corporate behavior. Companies can reorganize their work by eliminating or combining unnecessary or expensive organizational positions or investing in technologies that increase labor productivity without having to increase staff numbers. They can also use slack resources by resorting to overtime work, regaining the efficiency of underused personnel, changing part-time contracts, and encouraging internal mobility. Lastly, companies could reuse workers who have been laid-off without affecting unemployment statistics [26] [27].

In the recessionary cycles of the economy, the reduction in market demand

${ }^{3}$ Vacancies are defined as the number of positions not covered by personnel that the employer must fill to meet the company's needs for the production of goods and services. The vacancy does not always give rise to an explicit and public demand for work because the employer may not be aware of the real needs for personnel or may decide to rationalize the organization of work without increasing the workforce [24] or even decide to use the internal labor market. When a vacancy is made explicit in quantitative terms and made public in the labor market it can be used as a proxy for the economic cycle and labor demand [11] [25] [26] [27] [28] [29] [30] [31]. ISTAT has given a rigorous but more restrictive definition than the one just described, consistent with its purpose of statistical survey. For vacancy, the statistical institute means those "paid, new or existing jobs, vacant or about to become so, for which the employer actively seeks, on a certain date, a suitable candidate outside the company and is willing to make additional efforts to find it" [32] [33]. 
discourages the productive ambitions of companies that aim to implement strategies to reduce or limit employment, with the result that the demand for labor tends to decrease or to completely disappear. This leads to an excess of labor supply with a relative lowering of average salary levels in the market. Under these conditions companies are inclined: a) to favor the outflows of personnel (layoffs, early retirements, relocation of excess personnel); b) to maintain employment in the internal labor market by enhancing existing human capital (reductions in working hours, part-time contracts, work sharing) [10] [20]; c) to raise the quality standards of recruitment should a certain number of positions need to be filled. But the phases of depression are not always accompanied by an increase in unemployment. Indeed, it is possible that, due to excessive competition on the supply side and the general decrease in wages, part of the workforce becomes inactive and is not included in unemployment statistics. Firms may also have a distorted perception of the regressive cycle by underestimating its extent and duration or evaluating institutional restrictions on dismissal as overly burdensome by deciding to maintain existing employment. So there are many reasons that lead to the existence of correlations between trends in the economy, the labor market and the organizational behavior of companies. Some of these behaviors, as we have seen, concern recruitment. It is worthwhile to take a closer look at what the effects of these correlations have on personnel recruitment processes.

\section{Imbalances in Labor Markets and Personnel Recruitment}

The studies which have looked into the relationship between the labor market and the personnel recruitment can be linked back to Job Search Theory [10] [34] [35] [36] [37]. In the presence of an imperfect labor market and information asymmetry between those who buy and those who sell, the search for personnel, like any other process of searching for goods and services, generates costs and takes time [28] [38] [39]. The employer sets the minimum acceptable employment standard for a worker to be hired (reservation quality) based on their own scale of preference and looks for people to hire until the marginal benefits obtainable from subsequent research are greater than the necessary marginal costs to carry them out. Once the employer has ascertained the quality of a worker through selection methods (curriculum vitae, tests, questionnaires, simulations, interviews, references, internships, trial periods, etc.), and it is greater than or equal to the estimated minimal standard, the research process will stop and the worker will be hired, otherwise the process will continue [10] [37]. According to research theory, the problem with imperfect markets and information asymmetries is tackled by improving the processes of production and dissemination of information on the labor market. This tends to be carried out not only on the individual initiative of those who demand and supply labor but also through labor policies and third-party intermediaries that guarantee information services and market transparency. 
For informative purposes, problems posed to employers related to market imbalances (finding qualified personnel, discriminating against excess workforce, reducing the time and cost of recruitment, predicting job seeking behaviors) place the issue of effectiveness at the center of the debate of information-based personnel recruitment. Many studies focus on these aspects. The study by Henkens et al. based on multiple regression techniques, considered the labor market as the independent variable and recruitment strategies as the outcome variables [14]. The study found that in areas where unemployment was lower, employers' recruitment efforts were more intense as organizations faced problems with labor shortages and high competition.

Sabatier argues that the recruitment process is much more complex when the competition between companies is high while it becomes easier when a large number of jobseekers are available [15]. In the event of excess labor demand, the ratio between the number of applications and the available places tends to be lower. This pushes companies to compete with each other to attract valuable human resources that are not abundant on the market: the reservation wages of job seekers tend to increase, making it harder and more expensive to bring the parties together and also lengthening the duration of vacancies. In other words, recruitment processes become more difficult [40]. Conversely, in the event of excess labor supply, the ratio between the number of candidates and available places has a tendency to increase [41]. This leads candidates to compete with each other for a limited number of positions. Competition tends to lower reserve wages, increase the probability of finding a good match (information on the few places available is widespread) and decrease the duration of vacancies [13]

Olatunji and Ugonji's study [42] on the role of recruitment in organizational development processes starts from the premise that "in recent years, the labour market has swung back in favour of employers. Now the problem is not so much of attracting candidates, but in deciding how best to select them [43]." Lewis, quoted by Olatunji and Ugonji, sees the problem in this way: "in practical terms, attracting applicants is less of an issue, but administration and deciding whom to offer employment to are more difficult with large numbers", and warns also of the fact that "the present situation encourages employers to set tight specifications for all but the scarcest of jobs. Even with this strategy employers are being faced with large numbers of well-qualified candidates, and so recruitment processes become more time-consuming and problematic [44]." Efficient administration of recruitment processes, selective appointments and restrictive requirements, are all problems determined by information complexity due to an oversupply of labor.

Rasmussen and Hunt look at the problems of turnover and retention in New Zealand [22]. The research showed that in the expansive cycles of the economy with an increasing demand for labor and growth of company staff, companies in that country had to implement substantial changes in staffing systems by adopting strategies for excess staffing, internal mobility and outsourcing. In just over ten years, New Zealand has had high rates of economic growth and employment 
going from an unemployment rate of $11.2 \%$ in 1992 to $4 \%$ in 2004 . Some sectors such as hospitality, retail distribution, fast food and call centers have suffered more recruitment problems than others due to unexpectedly less attractive human resource management policies (low salaries, temporary contracts, poor career opportunities). This means that in expanding economies the competition for the recruitment of a scarce labor force can be influenced by a weakness in human resource management policies that pushes the workforce to turn to the most attractive sectors [15].

The efficiency of recruitment channels can increase the complexity of the recruitment process. In high-unemployment labor markets, the development of professional intermediation and technological platforms on the Internet can exacerbate rather than contain oversupply. This increases the problems of adverse selection for employers, who are faced with an indiscriminate mass of candidates for each job advertisement [45]. Research has shown that in the case of a high number of potential candidates, employers are prone to prefer private recruitment methods which act as a filter and also give more reliable information on the personality, motivation and adaptability of the applicants [46].

The results of the studies just presented give us an idea of how well-organized personnel recruitment processes play a strategic role in managing the markets with high demand and high labor supply. Effective recruitment strategies would allow for a better management of different situations of imbalance in the labor market which further exacerbate the difficulties in gathering information already inherent in this particular market [45].

\section{Imbalances in Labor Markets and Personnel Recruitment Behaviors}

In addition to identifying the strategic role of recruitment in today's labor markets, studies have also highlighted specific recruitment behaviors related to labor market dynamics ${ }^{4}$. The aforementioned study by Sabatier showed that the macro-economic context in France influences the choice of the recruitment channel and, in particular, whether or not to use public intermediaries [15]. When the economy is expanding, demand is high and competition between employers is high, companies tend to resort to public job advertisements that generate a greater number of applications (such as printed ads or online ads) [47] [48]. When, on the other hand, the economy is in recession, unemployment is on the rise and the competition among those seeking jobs is stronger, French compa${ }^{4}$ For specific recruitment behaviors we intend here the decisions concerning the employer's choice of the different recruitment channels. According to a well-established classification, used to describe the behavior of job seekers [51], the following can be distinguished: 1) formal and informal channels, depending on whether the employer makes use of institutional actors and makes the vacancy public or uses private relationships (family, parental, friendships, social, professional, knowledge); 2) direct and indirect channels, when the employer looks for personnel with or without the help of intermediaries; 3 ) traditional and innovative channels, depending on whether the use of the channel is widespread and consolidated over time or of recent use and introduction; 4) passive and active channels, depending on whether the channel is used as a simple receiver of curriculum vitae or as an active research tool for candidates. 
nies turn to public intermediaries who would guarantee placing a filter on candidacies [49].

A study on personnel recruitment in the Dutch labor market started from the premise that the way employers look for potential candidates is contingent on the general economic conditions existing at a given time [13] [50]. It found that the general conditions of the economy influence the extensive recruitment of personnel, in other words, it relies on the number of candidates. In particular, it was noted that in tight markets, extensive recruitment was more difficult than it was in slack markets ${ }^{5}$. Employers reacted to these situations by increasing or decreasing public job announcements depending on market conditions [13]. Ultimately, what seems to emerge from the study is that employers' recruitment behaviors are anti-cyclical in the sense that they tend to solicit or limit the demand for labor by relying on publicity for vacant positions.

Public job announcements can become a strategic lever to manage the diverse situations that may arise in labor markets. For example, in markets with a scarce labor supply, advertising a job through public channels may require less restrictive requirements and be aimed at a wider audience so as to generate a greater number of applications while in labor markets with a high supply the advertisements could envisage more stringent requirements so as to discourage a disproportionate number of candidates [27] [42].

Another empirical study on the Dutch labor market [14], conducted with reference to a period of labor supply difficulties (second half of the 1990s), found that employers were more inclined to actively search for personnel for vacant positions. The active search channels most used in that context were in order of frequency: 1) the use of social networks to contact people already employed; 2) direct contact with educational institutions; 3 ) direct contact with staff of other companies; 4) special events such as recruitment days and trade fairs; 5) internal and external databases or career sites; 6) announcements on its website.

An issue that has many consequences on employers' recruitment decisions and which has received various types of confirmation in the field is the use of social networks [6] [45] [52] [53]. In markets with a high demand for labor, which are transparent and moderately regulated, such as those in Central and Northern European and Anglo-Saxon countries, weak social relationships, in other words, those built on the basis of personal identity, are more frequent and appreciated on an organizational level. In markets with low labor demand, where available information is scarce and there are many rules, such as European Mediterranean countries, strong social relationships, based on belonging to a social, ethnic, professional or family group, are more frequent and socially ac${ }^{5}$ Tight and slack markets are two expressions of economic literature used to indicate respectively a situation of excess demand (tightness) or excess supply (slackness) in the labor market. These situations are measurable. There are tight markets when the ratio between the candidates (as numerator) and the vacancies (denominator) is low or decreasing compared to a historical series taken into consideration. We have slack markets when this ratio is high or increasing compared to the historical data. There is no benchmark for these phenomena. It must always be assessed with regard to the economic and social context in which excess demand and excess supply are viewed. 
cepted [23] [54].

A study on employers' recruitment behaviors in recovering economies observed the following phenomena concerning recruitment and intermediaries [55]: 1) in recovering economies the quality of the work required increases [56]; 2) people who already have a job search more often for better jobs [57];3) public search channels such as printed ads and online announcements are used more; 4) the public employment centers, although they are repositories of large quantities of curriculum vitae, are less used because they are populated by unskilled and unmotivated people, due to their fear of losing the subsidies of which they are beneficiaries; 5) in conditions of recession and an oversupply of labor the public employment centers would seem to be more attractive as they would expose the employer to a smaller number of candidates due to a filter effect that the centers would be able to carry out.

A study conducted in Germany analyzed how information and communication technologies (ICT) can help manage the problem of screening in slack and tight markets respectively [58]. A company operating in the health sector advertised 400 new jobs during the year and received 32,000 applications. The company adopted the following measures: creation of a centralized database and standardized application management software; progressive transition from paper and e-mail submission methods to applications with stricter formats created by the new platform; the use of software designed to automatically publish job positions and profiles; acceptance of non-generic candidates but for single positions, so as to create homogeneous groups of numerically manageable candidates.

A company operating in the field of industrial semiconductors was looking for mainly technical and engineering personnel who were difficult to find in the target labor market. The company created a centralized database, used an external service company and developed IT connections with university channels, all in an integrated way. The preferred reception channels became the corporate website and internet portals, even though applications made by traditional means continued to be provisionally accepted.

The study by Houseman et al. (2001) examines two cases of recruitment through recruitment agencies during a period of growing labor demand in the 1990s in the USA [59]. Under these conditions, the use of intermediaries improved efficiency in terms of bringing the two parties together, from the point of view of general costs and effective recruitment, but also from the point of view of labor costs. The agencies in fact, thanks to the economies of scale which they used in the supply of personnel, paid better salaries and were able to speed up the recruitment process more so than companies which turned to the labor market on their own [9] [60].

The previously mentioned report by Recruiter.com indicates some trends in personnel recruitment behaviors linked to the general or sectoral conditions of labor markets [3]. The first trend is that in sectors with high demand or high staff turnover, marketing strategies based on employer branding and advertising 
will be increasingly used to attract candidates and cover vacant positions. The second trend is that the ability to use big data and matching algorithms will be increasingly important because, in the event of oversupply, these tools would make it possible to filter the applications and simplify the recruitment processes; while, in cases of excess demand, they would allow more targeted and niche research programs to be carried out. The third trend is that the sectorial and territorial specialization of recruitment will be more functional both to the management of slack markets and to that of tight markets because of the restriction on the potential recruitment reservoirs and will allow for a more expert and targeted recruitment of candidates in a highly competitive context. The fourth trend is that of making use of profiles that can be derived from the social and professional media on the network which will make it possible to reduce the information asymmetries inherent in the personnel recruitment processes (Linkedin, Twitter, Facebook, Quora, Glassdoor, Knozen, etc.).

The Demos survey mentioned earlier, describes the following recruitment scenarios [1]: 1) organizations will face greater competition to find the right people for the right positions in all sectors and for all professions, whether it is a chef for a restaurant or a financial analyst for an investment bank; 2) more and more often it is the supply which "takes on" the demand and not vice versa: the strategies of attraction, consequently, become more and more important; 3) corporate performance is increasingly tied to the quality of human resources which companies are able to insert and retain; 4) the impetuous progress of ICTs enables research methods that allow for the discrimination, selection and filtering of information from a large mass of curriculum vitae. It follows, the survey argues, that the traditional distinction between a personalized recruitment for a few highly-qualified jobs and a standardized recruitment for numerous unskilled jobs loses meaning because the described scenarios push towards more sophisticated and targeted recruitment methods.

\section{A Comparison of Personnel Recruitment Behaviors in Italian Macro-Regions: An Empirical Verification}

The purpose of this section is to verify the relationships which exist between conditions of imbalance in the labor market and personnel recruitment behaviors in specific regional contexts. Observing labor markets on a local or regional basis does not present elements of particular originality from a theoretical point of view even if it allows for a more careful evaluation of some aspects of supply and demand linked to the restrictiveness of the market such as the industrial sectors present in an area, the type of occupations required, the geographical mobility of the offer, the culture of local recruitment, and the typical methods of job searching in a territory [2] [10].

Various studies have shown a certain differentiation of recruitment behaviors for regional areas. Research in the United Kingdom has shown that certain central and northern regions of the country with the highest unemployment such as Wales and Scotland made greater use of social networks than the southern re- 
gions of Merseyside or the East of England (excluding the London area).

Differences have also been noted between cities and the countryside. To find work in rural areas, social relationships were widely used, while in urban areas more formal and institutional channels were used [45] [61] [62]. A study conducted in Finland found that the introduction of the web-based service shortened the average duration of vacancies in some regions but not in others. In addition, employers in urban areas were more likely to benefit from the introduction of online service [63].

Another study, carried out with reference to the US urban labor markets, showed that areas of greater or lesser employment can coexist within the same country and that these differences influence personnel recruitment processes [64]. Dense labor markets, as Moretti defines them, are markets characterized by many buyers and sellers of labor concentrated in a limited geographical area. Cities like San Francisco, Boston and San Diego in the USA have much more intense exchanges than places like Portland or Chicago, where employment rates are certainly not negligible.

Dense labor markets are a very effective form of marketable to bring about numerous advantages in terms of recruitment. The first advantage is that employers and job seekers are able to meet up more easily thanks to the high probability of coming into contact with each other in a restricted area. The frequency of potential contacts in turn increases the chances that the encounters between demand and supply also become optimal matches and this in turn improves the overall efficiency of the market. The second advantage is that the density of the market increases the mobility of the labor force, which is the frequency with which people move from one job to another. A concentrated market of large dimensions, diversified and full of opportunities drives workers from other geographical areas or at the beginning of their careers to change jobs more frequently than in a restricted, specialized and poor job market. This determines professional growth and economic well-being for the workers [65]. A third advantage is linked to the ability to combat unemployment with support for the development of companies. When unemployment is not caused by a systemic recession but is due to micro-economic reasons linked to the individual company, the probability that a worker who works in an area with many employers remains unemployed is rather low. Just as low are the chances that an employer will not find a worker with the required skills, and that the position remains vacant for a long time limiting the company's operations.

Italy is a fertile ground for verifying our research as it presents more pronounced territorial differences from an economic, social and cultural point of view than anywhere else. Starting from a traditional structural dualism of the economy and the labor market, the country has seen its territorial inequalities grow in recent years, also due to the 2007-2008 crisis that affected many European and global economies. The employment rate of the active population has fallen throughout Italy, but in the South, where it was already very low, it fell further to $42.0 \%$, almost $18 \%$ lower than in Central Italy and $21 \%$ lower than in 
the North. The statistics are indicative. In the Central-Northern regions the majority of the active population is occupied (ranging from 69\% in Trentino Alto Adige and $65.3 \%$ in Lombardy to $57.5 \%$ in Lazio), while in the South the percentage of employees is always at below $50 \%$, with lows in Calabria (39.4\%) and Sicily (39.6\%) and with an increasingly inactive population [66]. The territorial differences between the north and the south of the country are confirmed not only on the quantitative level but also on the qualitative one with unemployment rates for skilled workers in the South always higher than those of the Center-North [20] The same labor policies seem to produce different effects due to these disparities: more effective and efficient in terms of employment development and protection of work incomes in the most developed areas of the country, less effective and expensive in less wealthy areas [67].

Therefore it becomes interesting to compare regional labor markets and specific recruitment behaviors. This would allow us to verify the existence of correlations between labor market imbalances and personnel recruitment behaviors. To this end, we have taken into consideration the four Italian macro-regions: the North-West, the North-East, the Center and the South including the Islands. Traditionally considered to have the own particular entrepreneurial and working culture, the Italian macro-regions present very different economic, social and administrative data. The data that is of interest here relates to the unemployment rates that are assumed to be representative of labor market imbalances in the areas considered. This allows us to make a comparison between different territorial actualities in terms of employment dynamics. According to the ISFOL data for the year 2013, the four Italian macro-regions have progressively increasing unemployment rates: the North-East $8.7 \%$, the North-West $9.4 \%$, the Center $11.2 \%$, the South and the Islands $19.5 \%$, with a national average of $12.3 \%$ [68]. The data are representative of regional unemployment in the country and are consistent with the employment rates shown above [66].

To further verify the territorial differences existing in the various areas of the country, INFOJOB data were used, an online recruitment platform and primary network operator with $33.3 \%$ of vacancies published in Italy [69] $]^{6}$. The INFOJOB data, with regard to the year 2015, claim that the North-West is in first place as the macro-region with the highest number of online vacancies with $44 \%$ of the total, followed by the North-East (28.70\%), then the Center $(19.70 \%)$, next the South $(5.80 \%)$ and finally the Islands (1.80\%). The same distribution, but with slightly different values, is recorded for the number of applications, with the North-West at $54.80 \%$, followed by the North-East (22.30\%), the Center (16.60\%), the South (4.90\%) and the Islands (1.40\%).

Further research went into the relationship between labor supply and demand in relation to the unemployment rate of the macro-regions and of the country. INFOJOB measures this ratio in terms of the number of applications for a single ${ }^{6}$ This data was kindly released by INFOJOB and has not been made public. I therefore thank both the company and Ms. Francesca Mari, Content Marketing Specialist and correspondent for INFOJOB, for the availability and collaboration provided. 
online job offer ${ }^{7}$. The report shows 73 applications for each job offer published in the North-West, the highest number of the macro-regions. The North-East has a ratio of 45.5, the Center of 49.3 the South of 49.9 and the Islands of 44.1, all much lower than the first. The national average is 58.5. This means that the North-West (Valle d'Aosta, Piemonte, Liguria, Lombardia), traditionally the most developed area of the country, is also the most attractive area in terms of supply. It is probable that this high ratio between labor supply and demand found in the North-West is not due to a lack of labor demand but rather due to the other higher unemployment rates of the other macro-regions which generate strong territorial mobility of the labor force towards that area.

What recruitment behaviors can be observed in these macro-regions characterized by such different contextual conditions? Research by EXCELSIOR, conducted on a sample of 100 thousand Italian companies with reference to a period of time ranging from 2010 to 2015, provides us with useful information in this regard. The points of interest observed in the research refer to three variables: 1) the motivations of Italian companies to hire; 2) the difficulties in finding the workforce; 3 ) the choice of recruitment channels [70].

The motivations of Italian companies to hire can be divided into expansive and conservative. The former is based on optimistic forecasts of economic development and the latter on prudential or not very confident forecasts of economic growth. Expansive motivations are measured by EXCELSIOR on the basis of the following indicators: 1) forecasts of growth in market demand, 2) developmental needs of new products and services; 3 ) the need to expand sales, locations or departments. Conservative motivations are measured by: 1) replacement needs for outgoing employees; 2) intentions to adapt staff only for seasonal work and activities; 3) resumption of external work and/or temporary workers. In a certain context, that of 2015, of relative recovery of the economy of the country the EXCELSIOR research shows a growth in expansive motivations to hire and a reduction in the conservative ones. In other words, companies increased their workforce to improve development and production departments and strengthen sales structures [70]. In the context of perceived economic development we can say that managerial initiative pushes towards a net growth of company staff. This is in line with the forecasts of economic cycle theories.

The data on the difficulties in procuring staff are interesting. The number of companies which run into difficulties in finding and selecting personnel is correlated to the amount of demand and supply of labor. Although demand increased in the country during 2015, the relationship with the supply has improved only slightly, as this has continued to grow due to greater participation in the labor market. At the end of 2014, over 3.4 million people were looking for work, equal to 4.7 potential candidates for each position available, while at the end of 2013 the ratio was 5.2 [70]. The general perception is of a continuous reduction of companies which believe they have difficulty in finding personnel. ${ }^{7}$ For similar methodologies, see the following studies: [13] [14] [27]. 
Looking at the data on a geographic basis we note that going from the north to the south of the country the number of firms that think they have difficulty in finding personnel is reduced, with maximum peaks of $16.9 \%$ in the North-East and minimum peaks in the South and Islands (10.8\%).

These data are entirely consistent with the rising unemployment rates found along the peninsula. Companies that think the problems they face in recruitment are due to an insufficient number of candidates (a typical attitude of employers who have full relative employment) decreases from the north to the south of the country. The causes of these difficulties are identified in the fact that: a) few people are able to perform (or are willing to do) the work required; and that: b) work is in great demand and there is competition between employers. In other words, the central-northern areas of the country, which are those with the highest occupation, express the typical signals of the tight labor markets described in the course of this study.

The industrial and high-tech sectors tend to find it even more challenging to recruit staff compared to the service sectors. We refer to the metallurgical, electrical, IT, chemical and pharmaceutical sectors and to the construction of industrial machines and transport vehicles. The same difficulties are encountered in some service sectors, despite the fact that the sector as a whole shows it to be less problematic for the industry in finding personnel. These are the fashion sector, advanced business services, education and training services, and media and communication. Even the largest companies with over 50 employees have difficulties in finding personnel. This is probably due to the productive and managerial complexity of these organizations which requires specialized workers which the Italian labor market struggles to offer [70].

The choice of recruitment channels indicates there is a certain variance between the regions, despite the general tendency of Italian companies to look for staff through informal channels ${ }^{8}$. In the North-West of the country, $61.2 \%$ of companies resort to informal channels while the remainder use corporate databases, job boards, job centers or other. The North-East has roughly the same data with $60.8 \%$ of companies using informal channels. However, the number of companies that use informal channels tends to grow significantly, moving from areas of low unemployment to areas of greatest unemployment in the country (in the Center: 64\% of companies; in the South and Islands: 72.1\%) [70]. This is in line with the studies analyzed in this paper which show that in the areas of a country where there is greater economic growth, demand for labor and skilled jobs, the informal channel is less used than formal channels (corporate databases and institutional intermediaries). In less developed regions, on the other hand, the use of informal and social channels tends to remain prevalent with respect to

${ }^{8}$ The informal channel consists of a combination of direct and indirect employer knowledge. According to Excelsior survey data, direct knowledge of the candidates meets the growing tendency of companies, increasing by $9.7 \%$ from 2010 to 2014, while the channel of networks and suppliers tends to decrease, going from $11.9 \%$ to $6 \%$ from 2010 to 2014 . The use of specialized operators also dropped from $8.5 \%$ to $6.1 \%$ in the same period (although it tends to increase significantly as the size of the company increases) and traditional channels such as printed advertisements. 
all other channels [23].

\section{Results, Research Contributions, Managerial Implications and Limitations of This Study}

In this study we have addressed the issue of the relationship between personnel recruitment and the general conditions of the economy and the labor market. The results received are summarized as follows. In both the expansion and contraction cycles of the economy and labor demand, the search for personnel takes on a strategic role in that the organizational function tackles a series of very different criticalities (the need to find skilled workers in a market of low supply, to restrict the oversupply of labor, the use of advanced recruitment techniques).

In the expansion cycles of the economy the demand for labor tends to increase, on condition, however, that the perception of the companies is in line with the trend of the cycle. The expansion does not automatically lead to more employment as companies can adopt wait-and-see or defensive behaviors that translate into processes of optimizing the use of resources and reorganization of labor, a type of labour-saving, which does not generate new jobs but rather the retention of the existing position.

In the recession cycles of the economy the demand for labor tends to decrease. Companies reduce company staff and raise recruitment quality standards. The recession does not automatically determine an increase in unemployment as job seekers may decide to leave the market voluntarily because they are discouraged by the recession. Other reasons may be: a very prudent perception of the recession and the institutional constraints on dismissal in companies being too expensive. Companies in these cases may decide to maintain existing staff so as to accumulate human capital and avoid incurring excessive dismissal costs.

In the expansion cycles of the economy and the demand for labor, companies adopt specific recruitment behaviors that can be summarized as follows: 1) they implement anticyclical behaviors with scarce job offers; 2) use public and active research channels that attract higher numbers in terms of quantity and quality; 3) compete with other employers through marketing strategies in the labor market (employer branding, job advertisements, increases in wages); 4) rely more on weaker and less informal social relationships; 5) use modern ICT to carry out more targeted and selective personnel searches; 6) tend to lower the quality standards of recruitment.

Even in the recession cycles of the economy and labor demand, companies adopt specific research behaviors: 1) they discourage the supply of labor through defensive techniques that require the use of ICT to simplify, discriminate and sectionalize recruitment processes; 2) use private informal channels and rely more on strong social relationships; 3 ) in some cases are directed to public and private intermediaries in order to outsource recruitment costs and benefit from public measures; 4) may use public intermediaries to act as filters on supply.

Studies on regional labor markets show that within country areas of greater or lesser employment can coexist and impact staff recruitment processes in differ- 
ent ways. The empirical verification carried out on the Italian macro-regions confirmed that by moving from more developed areas with greater employment to areas of lower growth and lesser employment, companies claim that they have less difficulty in recruiting personnel and adopt defensive recruitment practices to favor informal channels and strong social relationships.

This study's contribution to the current state of knowledge and future research should be considered in a broader macro-economic context with regard to recruitment issues and the dynamics of the labor market towards which $\mathrm{Hu}$ man Resource Management Studies, with rare exceptions in Italy, have paid little attention [9] [10] [60] [71] [72] [73]. In this context, the study presents interesting insights into the analysis and interpretation of the phenomena under investigation. It makes use of original data and information (INFOJOB data); furthermore, carrying out a reasoned analysis, development and systematization of existing data and sources.

The managerial implications consist in focusing on the strategic role of personnel recruitment regarding the macro-economic context and the dynamics of the labor market. This is an organizational function that is very often underestimated, assigned to human resource professionals who often end up being absorbed by activities that are considered more important. In other contexts, it is a function left to chance, initiative or the personal intuition of entrepreneurs and managers. This study has limitations. The literature on personnel recruitment is abundant and multidisciplinary. Therefore the sources analyzed may not be exhaustive of the literature on the subject and not capture all the complexity of the relationships between different disciplinary contributions.

\section{Conflicts of Interest}

The authors declare no conflicts of interest regarding the publication of this paper.

\section{References}

[1] Gallagher, N. and O’Leary, D. (2007) Recruitment 2020. Demos, Pickard Julie, London, 58-59. https://www.demos.co.uk

[2] Kelly Services (2015) Hiring Manager Survey. https://www.kellyservices.it

[3] Recruiter (2014) Recruitment Technology Trends. https://www.recruiter.com

[4] Costa, G. and Gianecchini, M. (2013) Risorse Umane. MacGraw-Hill, Milano, 153-172.

[5] Noe, R.A., Hollenbeck, J.R., Gerhart, B. and Wright P.M. (2010) Human Resource Management. MacGraw-Hill, Chicago, IL.

[6] Dessler, G. (2015) Fundamentals of Human Resource Management, Global Edition Pearson International.

[7] Doeringer, P.B. and Piore, M.J. (1971) Internal Labour Markets and Manpower Analysis. M.E. Sharpe, Inc., Armonk, New York.

[8] Osterman, P. (1987) Choice of Employment System in Internal Labour Market. Industrial Relations: A Journal of Economy and Society, 26, 46-67. 
https://doi.org/10.1111/j.1468-232X.1987.tb00693.x

[9] Ferrara, M. (2008) La gestione del lavoro flessibile. Giappichelli, Torino.

[10] Manzolini, L. (1984) Economia e organizzazione delle transazioni di lavoro in impresa. Giuffrè, Milano.

[11] ISFOL (2016) I canali di intermediazione e i servizi per il lavoro. Collana Research Paper, 31. https://www.isfol.it

[12] Mortensen, D.T. and Pissarides, C.A. (1994) Job Creation and Job Destruction in the Theory of Unemployment. The Review of Economic Studies, 61, 397-415. https://doi.org/10.2307/2297896

[13] Russo, G., Rietveld, P., Nijkamp, P. and Gorter, C. (2000) Recruitment Channel Use and Applicant Arrival: An Empirical Analysis. Empirical Economics, 25, 673-697. https://hal.archives-ouvertes.fr/hal-00825991 https://doi.org/10.1007/s001810000042

[14] Henkens, K., Remery, C. and Schippers J. (2005) Recruiting Personnel in a Tight Labour Market: An Analysis of Employers' Behaviour. International Journal of Manpower, 26, 421-433. https://doi.org/10.1108/01437720510615116

[15] Sabatier, M. (2010) Filling Vacancies: Identifying the Most Efficient Recruitment Channel. Economics Bulletin, 30, 3355-3368. https://hal.archives-ouvertes.fr/hal-00825991

[16] Holt, C. (1969) Improving the Labour Market Trade-off between Inflation and Unemployment. American Economic Review, 59, 135-146. https://www.jstor.org/stable/1823663

[17] Andolfatto, D. (1996) Business Cycles and Labor-Market Search. The American Economic Review, 86, 112-132. http://www.jstor.org/stable/2118258

[18] Devereux, P. (2004) Cyclical Quality Adjustment in the Labor Market. Southern Economic Journal, 70, 600-615. https://www.jstor.org/stable/4135333 https://doi.org/10.2307/4135333

[19] Shimer, R. (2005) The Cyclicality of Hires, Separations and Job to Job Transitions. Federal Reserve Bank of St. Louis Review, 87, 493-507. https://files.stlouisfed.org/files/htdocs/publications/review/05/07/Shimer.pdf https://doi.org/10.20955/r.87.493-508

[20] Destefanis, S. and Fonseca, R. (2005) Curva di Beveridge, mismatch e domanda di lavoro qualificato. In: Mocavini, A. and Paliotta, A.P., Eds., La domanda di lavoro qualificato in Italia, Isfol, Franco Angeli, Milano, 161-162.

[21] Basu, P. (2006) Understanding Labor Market Frictions: A Tobin's Q Approach. University of Durham (U.K.). Money, Macro and Finance Study Group Meeting, York University, Unpublished Paper.

[22] Rasmussen, E. and Hunt, V. (2007) Turnover and Retention in Tight Labour Market: Reflecting on New Zealand Research. New Zealand Journal of Employment Relations, 32, 1-16.

https://www.questia.com/library/journal/1P3-1385699431/turnover-and-retention-i n-a-tight-labour-market-reflecting

[23] Reyneri, E. (2011) Sociologia del mercato del lavoro. Il Mulino, Bologna.

[24] Ingrassia, R. (2018) “The Same Staff Can Be Enough”. Employers' Resilience Strategies in Recruitment Decisions. American Journal of Industrial and Business Management, 8, 607-618. https://doi.org/10.4236/ajibm.2018.83040

[25] ISTAT (2008) Rapporto annuale. La situazione del Paese. Istituto Nazionale di Statistica, Roma, 48-49. https://www.istat.it 
[26] CNEL (2014) Rapporto sul mercato del lavoro 2013-2014, 202. https://www.cnel.it

[27] Kurekovà, L., Beblavý, M. and Thum-Thysen, A.E. (2013) Online Job Vacancy Data as a Source for Micro-Level Analysis of Employers' Preferences. A Methodological Enquiry. First International Conference on Public Policy (ICPP), Grenoble, France, 26-28th June 2013, 1-17.

[28] Autor, D.H. (2009) Introduction. In: Autor, D.H., Ed., Studies of Labor Market Intermediation, National Bureau of Economic Research, University of Chicago Press, Chicago, IL, 1-23.

[29] INTOO (2011) Outplacement. Testimonianze e prospettive, Panorama Economy, Milano, 6-7.

[30] Ichino, P. (2015) Il lavoro ritrovato. Mondadori, Milano.

[31] Lucarelli, A. (2011) Vacancies and Hirings: Preliminary Evidence from a Survey on Italian Eployers. Rivista di Statistica Ufficiale, 2-3, 21-53.

https://www4.istat.it/it/files/2012/04/secondocapitolo.pdf

[32] ISTAT (2016) Rapporto annuale. La situazione del Paese, Istituto Nazionale di Statistica, Roma, 275. https://www.istat.it

[33] EUROSTAT (2017) Euro Area Job Vancancy Rate at 1.7\%. Newrelease Euroindicator, 50. https://www.ec.europa.eu/eurostat

[34] Mortensen, D.T. (1970) Theory of Wages and Employment Dynamics. In: Archibald, G.C., Alchian, A.A. and Phelps, E.S., Eds., Microeconomic Foundations of Employment and Inflation Theory, Norton, New York, 167-211.

[35] Mortensen, D.T. (1987) Job Search and Labour Market Analysis. In: Ashenfelter, O. and Layard, R., Eds., Handbook of Labor Economics, Elsevier, North land, [Amsterdam, 849-919. https://doi.org/10.1016/S1573-4463(86)02005-9

[36] Alchian, A.A. (1970) Information Cost, Pricing and Resource Unemployment. In: Archibald, G.C., Alchian, A.A. and Phelps E.S., Eds., Microeconomic Foundations of Employment and Inflation Theory, Norton, New York, 27-52.

[37] Tridico, P. (2009) Flessibilità e istituzioni nel mercato del lavoro: dagli economisti classici agli istituzionalisti. Economía \& lavoro, 43, 113-139. https://dialnet.unirioja.es/servlet/articulo? codigo $=6118141$

[38] Simon, H. (1947) Administrative Behavior. MacMillan, New York.

[39] Garibaldi, P. (2005) Economia delle risorse umane. Il Mulino, Bologna.

[40] Passerini, W. (2016) Imprese a caccia di personale non trovano 40 mila lavoratori. http://www.lastampa.it

[41] Live Sicilia, Caso Mediaworld. http://www.livesicilia.it

[42] Sule, O.E. and Elizabeth, U.I. (2013) Impact of Personal Recruitment on Organisational Development: A Survey of Selected Nigerian Workplace. International Journal of Business Administration, 4, 79-103. https://doi.org/10.5430/ijba.v4n2p79

[43] Cole, G.A. (2002) Personnel and Human Resources Management, Educational Low-Priced Sponsored Texts with Continuum. London.

[44] Lewis, C. (1985) Employee Selection. MacDonald \& Evans Hutchinson, London.

[45] Green, A.E., de Hoyos, M., Li, Y. and Owen, D. (2011). Job Search Study: Literature Review and Analysis of the Labour Force Survey. Institute for Employment Research, University of Warwick/Department for Work and Pensions Research, Report No. 726. http://research.dwp.gov.uk/asd/asd5/rrs-index.asp

[46] Nunn, A., Bickerstaffe, T., Hogarth, T., Bosworth, D., Green, A. and Owen, D. (2010) Postcode Selection? Employers' Use of Area- and Address-Based Informa- 
tion Shortcuts in Recruitment Decisions. Institute for Employment Research, University of Warwick/Department for Work and Pensions Research. Report No. 664.

[47] Collins, C.J. and Han, J. (2004) Exploring Applicant Pool Quantity and Quality: The Effects of Early Recruitment Practice Strategies, Corporate Advertising, and Firm Reputation. Personnel Psychology, 57, 685-717. http://digitalcommons.ilr.cornell.edu/articles/44 https://doi.org/10.1111/j.1744-6570.2004.00004.x

[48] Edwards, M.R. (2010) An Integrative Review of Employer Branding and OB Theory. Personnel Review, 39, 5-23. https://doi.org/10.1108/00483481011012809

[49] Balestrieri, G. (2016) Il lavoro corre online: un milione le offerte pubblicate in rete. https://www.repubblica.it/economia/2016/03/26/news/lavoro_collocamento-135697 $675 /$

[50] Burdett, K. and Cunningham, E.J. (1998) Toward a Theory of Vacancies. The Journal of Labor Economics, 16, 445-478. https://www.jstor.org/stable/10.1086/209895 https://doi.org/10.1086/209895

[51] Ingrassia, R. (2016) Jobseeking Behaviour Theory: le implicazioni per i datori di lavoro e loro processi di reclutamento. Annali della Facoltà di Economia, LXIX-LXX, Università degli Studi di Palermo, 57.

[52] Granovetter, M.S. (1995) Getting a Job: A Study of Contacts and Careers. Harvard University Press, Cambridge, MA. https://doi.org/10.7208/chicago/9780226518404.001.0001

[53] Sicilian, P. (1995) Employer Search and Worker-Firm Match Quality. The Quarterly Review of Economics and Finance, 35, 515-532. https://doi.org/10.1016/1062-9769(95)90052-7

[54] Brown, D.W. and Konrad, A.M. (2001) Granovetter Was Right: The Importance of Weak Ties to a Contemporary Job Search. Group \& Organization Management, 26, 434-462. https://doi.org/10.1177/1059601101264003

[55] Sanders, M. and Welters, R. (2011) Recruitment in Recovery. Discussion Paper, Tjalling C. Koopmans Research Institute, Utrecht School of Economics, Utrecht University, 1-17.

[56] Krause, M. and Lubik, T. (2006) The Cyclical Upgrading of Labor and on-the-Job Search. Labour Economics, 13, 459-477. https://ideas.repec.org/s/eee/labeco.html https://doi.org/10.1016/j.labeco.2006.02.007

[57] Nagypal, E. (2006) Amplification of Productivity Shocks: Why Don't Vacancies Like to Hire the Unemployed? In: Bunzel, H., Christensen, B., Neumann, G.R. and Robin, J.-M., Eds., Structural Models of Wage and Employment Dynamics, Emerald Group Publishing Limited, Bingley, West Yorkshire;, 481-508. https://doi.org/10.1016/S0573-8555(05)75019-7

[58] Malinowski, J., Keim, T. and Weitzel, T. (2005) Analyzing the Impact of IS Support on Recruitment Processes: An E-Recruitment Phase Model. Proceedings of the Ninth Pacific Asia Conference on Information System, Bankok, Thailand, 7-10 July 2005, 1-12.

http://www.efinancelab.de/no_cache/publications/articles/year/2003/?user_wiwipub s_pi1\%5BshowUid $\% 5 \mathrm{D}=42$

[59] Houseman, S.N., Kalleberg, A.L. and Erickcek, G.A. (2001) The Role of Temporary Agency Employment in Tight Labor Markets. Industrial and Labor Relations Review, 57, 105-127. https://doi.org/10.17848/wp01-73

[60] Consiglio, S. and Moschera, L. (2016) Temporay Work Agency in Italy. Springer, Switzerland. https://doi.org/10.1007/978-3-319-44541-0 
[61] Lindsay, C., Greig, M. and McQuaid, R.W. (2005) Alternative Job Search Strategies in Remote Rural and Peri-Urban Labour Markets: The Role of Social Networks. Sociologia Ruralis, 45, 53-70. https://doi.org/10.1111/j.1467-9523.2005.00290.x https://strathprints.strath.ac.uk/39380/1/ruralis_final_paper.pdf

[62] Matthews, R., Pendakur, R. and Young, N. (2009) Social Capital, Labour Markets, and Job-Finding in Urban and Rural Regions: Comparing Paths to Employment in Prosperous Cities and Stressed Rural Communities in Canada. The Sociological Review, 57, 306-330. https://doi.org/10.1111/j.1467-954X.2009.01831.x

[63] Nivalainen, H. (2014) Internet-Based Employer Search and Vacancy Duration: Evidence from Finland. Labour, 28, 112-140. https://doi.org/10.1111/labr.12027

[64] Moretti, E. (2012) New Geography of Job. Marco Vigevani Agenzia Letteraria e Zoe Pagnamenta Agency.

[65] Wheeler, C.H. (2008) Local Market Scale and Pattern of Job Changes among Young Men. Regional Science and Urban Economics, 38, 101-118.

http://research.stlouisfed.org/wp/2005/2005-033.pdf https://doi.org/10.1016/j.regsciurbeco.2008.01.011

[66] ISFOL (2014) Rapporto di monitoraggio del mercato del lavoro italiano. I Libri del Fondo Sociale Europeo, Roma, 109. http://www.isfol.it

[67] ISFOL (2008) Dieci anni di orientamenti europei per l'occupazione (1997-2007). Rubbettino, Catanzaro, 212-215. http://www.isfol.it

[68] ISFOL (2017) Osservatorio Europa 2020.Analisi Quantitative.Dati regionali. http://www.isfol.it

[69] INFOJOB (2016) Osservatorio sul mercato del lavoro (Reserved Paper).

[70] EXCELSIOR (2015) La domanda di professioni e di formazione delle imprese italiane. Unioncamere. Ministero del Lavoro, Sistema Informativo Excelsior, Roma. http://excelsior.unioncamere.net

[71] Rugiadini, A. (1979) Organizzazione d'impresa. Giuffrè, Milano.

[72] Airoldi, G. (1980) I sistemi operative. Giuffrè, Milano.

[73] Costa, G. (1990) Economia e direzionedellerisorseumane. Utet, Torino. 